\title{
Sustaining safe practice: twenty years on
}

\author{
Susan Kippax*, Kane Race \\ National Centre in HIV Social Research, The University of New South Wales, Sydney NSW 2052, Australia
}

\begin{abstract}
This paper examines the ways in which populations at risk of HIV in the developed world have enculturated the knowledges and technologies of both the medical and the social sciences. By revisiting a number of review papers and by reviewing findings from a range of studies, we argue that gay men have appropriated information that has enabled them to sustain safe practices while they have eschewed information that has made maintenance difficult.

The paper describes a range of risk reduction strategies and compares the responses of populations at risk of HIV in the years before the advent of highly active antiviral therapy (HAART) with their responses after the introduction of HAART in 1996. We concentrate our argument on the changing responses to HIV risk of gay men, although occasionally illustrate our argument with reference to the responses of injecting drug users. The responses of gay men to risk post-HAART - particularly those who reside in Australia - speak to the adoption of a range of considered strategies, not altogether safe, to reduce harm.

We argue that such strategies need to be understood and addressed within a 'new' social public health, that is, a public health that takes what social analysis has to say seriously. The paper examines the differences between the traditional, the 'modern' epidemiological/clinical and the 'new' social or socio-cultural public healths and describes the tensions between the medical and the social science disciplines in their efforts to inform public health. Key concepts provided by social science such as agency (including individual and collective agency), alongside its methodological reflexivity are key to effective public health. The risk avoidance strategies adopted by gay men suggest a way forward by turning our attention to the ways in which medicine is taken in(to) their practice.
\end{abstract}

(C) 2003 Elsevier Science Ltd. All rights reserved.

Keywords: HIV; HAART; Risk; Gay men; Prevention

\section{Introduction}

This paper concerns the manner in which the medicoscientific disciplines and the social science disciplines are implicated with one another and together inform HIVprevention and health promotion. Sometimes the two disciplines work together, in both intended and unintended ways, and sometimes the relationship is antagonistic. This paper explores the relationships between them in terms of how HIV-prevention or risk avoidance is understood and enacted by populations at risk of HIV in the developed world, in particular, by gay men.

\footnotetext{
*Corresponding author. Tel.: +61-2-9385-6799; fax: +61-29385-6700.

E-mail addresses: s.kippax@unsw.edu.au (S. Kippax), k.race@unsw.edu.au (K. Race).
}

We are interested in HIV testing and antibody status, highly active antiretroviral treatments (HAART), viral load and categories of risk and how each is positioned in the narratives of both sets of disciplines, the medical and the social sciences. We argue that the history of HIV prevention and risk reduction can be viewed as a product of the tensions between the two sets of disciplines ${ }^{1}$ and the paradigms within which the research of these disciplines is framed. The relationship between the medical and the social sciences has changed over time - between pre-1996 when the social held sway, and post-1996 when we witnessed a switch to the dominance

\footnotetext{
${ }^{1}$ While we are aware that the medical sciences and the social sciences are not completely separate and acknowledge that there is some overlap between them, we focus here on the differences and resulting tensions between them.
} 
of medicine with the advent of relatively successful treatments and, more recently, the promise of vaccines. Although we have concerns about the impact of current medical dominance on prevention, we conclude that it is not only important to acknowledge the relevance of medicine as well as social science to prevention efforts, but that it is imperative that prevention takes medicine in(to) its practice.

The paper is divided into two sections: a review of the past-pre-1996; and of the recent past-post-1996 to 2001. In each of these time periods, we examine the impact of AIDS on the lives of people affected by HIV. In the main, we focus on gay men in the developed world and on the ways in which they have understood the risk of HIV transmission and responded to it. At each time period, we examine the role of medicine and the social sciences in their constructions of risk. We examine how gay men have enculturated medical and social scientific knowledges and technologies, that is, have appropriated and incorporated them into the structures of their everyday lives and made HIV-prevention and harm reduction work for them. Although a somewhat arbitrary division, because of the introduction of effective medical treatments, the post-HAART years are particularly challenging to populations at risk of HIV and, in turn, educators and prevention experts. As argued here, at one and the same time, treatments may pose a danger for prevention as well as offering some protection against HIV transmission.

\section{The early years-pre-1996}

The first phase of the response to HIV was a 'prevention only' phase, a phase which marks the recent past against which the introduction of treatments in 1996 can be foregrounded. Prevention has worked: in most northern European countries, in Australasia, and among certain populations in North America, both Canada and the United States, HIV rates declined (Anderson, 2000; Coates et al., 1996). In this period, in much of the developed world at least, there was a remarkable modification of sexual and drug use practice.

In a very important sense, the earliest moves to prevent the spread of AIDS occurred before social science and medicine entered the fray. In the developed world, supported by existing gay organisations, community and network structures, the very first HIV/AIDS education activities were produced by gay men and injecting drug users (Callen, 1983; Friedman et al., 1987; Friedman, Curtis, Neaigus, Jose, \& Des Jarlais, 1999). These activities occurred long before specific AIDS organisations were formed and before government health authorities responded (Ballard, 1989; Patton, 1990; Watney, 1990).
Although there were some false starts, governments and health authorities built on these early harm reduction activities. Medical and, somewhat later, social scientists began to play a part in advising both governments and non-government organisations by researching risk and informing prevention policy. During this time, the 1980s and early 1990s, the push for prevention of HIV transmission was in many ways straightforward - not easy - but prevention was all that there was and whatever the misgivings and lack of faith, as well as moral and ideological posturing, there was a sense of urgency.

Medical science most frequently positions risk as a problem for individuals - understood as the individual members of particular populations or groups. Categories of those at risk, 'risk groups' were enumerated by epidemiology: gay men, drug users, and sex workers were typically named and adolescents and women were occasionally added to the list. Somewhat paradoxically these categories became markers of risk and vulnerability: being at-risk coming to mean risk-to-others (Brown, 2000; Waldby, Kippax, \& Crawford 1995). For example, young gay men were positioned as vulnerable and at-risk, while gay men, as a group, were positioned as risk-takers who placed the young at risk. Heterosexual men were and to some extent continue to be absent from the list, while women occupied positions as both vulnerable (wives) and dangerous (sex workers) (Waldby, Kippax, \& Crawford, 1993).

Such 'risk group' categories position individuals in such a way that they are fully determined by the epidemiological narrative of risk: the epidemiological narrative easy to take for granted and left unchallenged by the mainstream because it is informed by wider cultural narratives about the location of disease and morbidity. Thus sexual difference, as in the case of 'gay', is conflated with deviance and, in turn, with immorality and disease. Similarly, women who for a variety of reasons engage in sex work are positioned as 'prostitutes', thus promiscuous and vessels of disease. This over-determination occurs because medical science uses the term 'group' in the same way as it uses the term 'population': as referring to a number of individuals identified merely by their membership of a particular population or group as 'gay', or 'bisexual' or drug user'. Indeed within CDC categories adopted by most developed countries, heterosexual transmission is deemed to be a 'risk' only if the sex occurs with a 'partner' who is known to be HIV-positive, a member of a 'risk group', or from a high prevalence country. Medical science's use of the term 'risk group' failed (and continues to fail) to carry any sense of social connectedness and shared meanings; the term was and is simply a marker of an imposed identity category which came to stand for risk.

These identity categories such as 'gay' or 'drug user' are themselves marked by particular behaviours- 
usually 'risky'. So as well as linking HIV to 'risk groups', other medical-boundary marking linked increased transmission risk to particular behaviours: homosexual/bisexual transmission; injecting drug use; and so on. (The use of the term 'bisexual transmission' illustrates a similar problem although this time via the conflation of identity with behaviour). With regard to sexual behaviour, risk was identified with forms of penetrative intercourse, especially anal and vaginal intercourse, and promiscuity.

Health promotion and HIV-prevention in the mid- to late 1980s came in a number of guises. There were differences within nations and between nations but, in general, in this early period most agreed that abstaining from or delaying sex, and limiting the number of sexual partners - preferably to one, were the most efficacious strategies (Bennett, 1987). Many educators and researchers (for example, Collomb \& Howard, 1988) advocated delaying intercourse until marriage for young heterosexuals - and, although under attack, the US Congress recently approved a \$20 million funding increase for abstinence-only education programmes (Washington Post, 2001). Monogamy was also advocated (Goedert, 1987): a sensible strategy from an epidemiological viewpoint but only if the monogamy is mutual and lasting and the sexual partners are seronegative.

There was also an acknowledgement that few people were willing to accept celibacy or abstinence and maintain it if adopted (Gochros, 1988) and condom use was advocated (Surgeon General's Report, 1986). Condom use was advocated for gay men as well as heterosexuals (Conant, Hardy, Sernatinger, Spicer, \& Levy, 1986; De Gruttola, Mayer, \& Bennett, 1986; Ross, 1987), but gay men were also urged to forego sex (van Griensven, de Vroome, Tielman, \& Coutinho, 1988). For example, in the early 1980s in the Netherlands, condoms were not as widely advocated as elsewhere in the developed world and gay men were asked to abstain from anal intercourse (de Zwart, Sandfort, \& van Kerkhof, 1998). Such advocacy had the desired decrease in HIV incidence - at least in the short term (van Griensven, de Vroome, Goudsmit, \& Coutinho, 1989).

Risk is located differently depending on one's position - as medical or social scientist, member of community or government (Haraway, 1991). Social scientists, while not ignoring the so-called 'risk groups', focused attention on practices. Their focus was more on the practices of groups than on the behaviours of individuals, where 'practices' unlike 'behaviours' are socially produced between people, intersubjectively, and are subjectively meaningful. Social practices inform particular behaviours or actions by particular individuals on particular occasions in particular locations and contexts.

Individualistic models of health promotion and prevention such as the Health Belief Model championed by medical researchers as well as by more psychologically oriented social scientists have been criticised by many social scientists especially those trained within the European tradition (Ingham, Woodcock \& Stenner, 1992; Kippax \& Crawford, 1993; Paicheler, 2000). As the analysis of cross-cultural European data on HIV transmission and sexual practice demonstrates, preventive behaviour is deeply rooted in social relationships and structured by social and interpersonal factors as well as by individual ones (Bajos \& Marquet, 2000). Concepts such as 'risk' must therefore be framed in terms that resonate with the historically formed understandings and interests of those who are the targets of health promotion efforts.

Both medical and social scientists deemed that unprotected penetrative sex and needle sharing were unsafe or 'risk' behaviours and practices, while safety and the reduction of harm was associated with the practice of condom use and the use of clean needles (Coates et al., 1996; Kippax, Connell, Dowsett, \& Crawford, 1993). However, while most social scientists distinguished, for example, the practice of unprotected anal intercourse between seroconcordant negative partners in a regular relationship from the practice of unprotected anal intercourse between partners of serodiscordant or unknown serostatus, medical scientists saw the behaviour of unprotected anal intercourse as the same-whatever the social context.

In the early 1990s when HIV testing became available, the practice of unprotected anal intercourse between seroconcordant negative partners in a regular relationship - 'negotiated safety' - was identified by researchers (Kippax, Crawford, Davis, Rodden, \& Dowsett, 1993; Kippax et al., 1997) and advocated by health educators-initially in Australia (Kinder, 1996). This practice, or variations on it, was also identified by researchers from a number of European countries including the United Kingdom (Davies, 1993; Elford, Bolding, Maguire, \& Sherr, 1999) and France (Adam, 1999), and in the Netherlands it was taken up as a harm reduction strategy (Davidovich, de Wit \& Stroebe, 2000). The practice of negotiated safety is a prevention strategy that allows for the relatively safe practice of discarding with condoms within seronegative regular relationships, as long as safe sex agreements are negotiated to cover sexual behaviour outside these regular relationships. As a strategy, negotiated safety bears some similarity to the strategy of monogamy, although as a practice, it is very different from monogamy. Unlike monogamy, negotiated safety advises that an agreement be reached about sexual practice outside the relationship: this agreement may include refraining from sex outside but is not limited to such an agreement. Rather, what is negotiated is that all sexual behaviour outside the regular relationship is safe. 
Risk is very differently positioned in these two strategies: the first, negotiated safety, informed by community practice and identified and formalised by social science; the second, monogamy, informed by an epidemiology which assumes that monogamy is mutual and lasting. While 'dispensing with condoms' within a monogamous relationship or a negotiated safety agreement may comprise the same behaviour, the practice constituted in the socially produced meanings of 'dispensing with condoms' is very different. In negotiated safety, there are no assumptions of HIV-negative seroconcordance and current and continuing fidelity, and men, acting as agents, make sense of the risk of dispensing with condoms within their relationships (both serially monogamous and sexually open) and modify their practice in a comparatively safe way. Public health informed by social science, which was in turn informed by what was going on (empirically) among gay men, acted to strengthen and publicise what was working and authorised negotiated safety. We refer to this socially informed public health as social public health and distinguish it from traditional public health with its focus on structural social and economic determinants. We also distinguish it from a 'modern' public health that is sometimes referred to as the 'new' public health, which is informed by epidemiology and medical science. In the remainder of this paper we concentrate on the distinction between the modern medical/epidemiologically informed public health and a social or socio-cultural public health.

Members of 'risk groups' played an important role in the development of HIV prevention policy. In Australia, parts of North America and much of Western Europe, government bodies sought out members of gay communities and drug user networks to inform their policies around the containment of risk and disease. Gay men, injectors, sex workers, became members of parliamentary committees and policy-making bodies. They acted as representatives of their constituencies: their inclusion meant that policy makers became well informed about risk practices. Government bodies engaged those for whom the relevant practices were meaningful (and those who understood this) as experts.

Furthermore, these same communities were resourced to develop peer education and sustain prevention efforts often on the basis of social research (Kippax, Connell, Dowsett \& Crawford, 1993; Ballard, 1998). Many gay men took up positions as educators and advocates in non-government organisations and, working alongside social researchers and public health officials, mobilised the fight against HIV in gay communities (Kippax \& Kinder, 2002). Countries and communities so advised witnessed widespread advertising of condoms, the eroticisation of 'safe sex' at least in campaigns aimed at at-risk populations, sex education in schools, and the open discussion of anal sex not only in gay but also in heterosexual contexts. Equally importantly, while acknowledging the association between risk and difference, the inclusion of 'risk groups' helped government bodies deal with and undermine the stigma and discrimination associated with the imagined 'other'.

All HIV harm reduction and health promotion strategies, both those advocated by medical science and those by social science, are informed by medical knowledge of transmission risk and antibody status. Condom use was, and continues to be, advocated by social and medical scientists and researchers (Conant et al., 1986; Kippax \& Kinder, 2002). With regard to other harm reduction strategies, there were and continue to be tensions, and these tensions are related to the scientific perspectives that inform medical and social science.

On the one hand, the strategies favoured by the medically oriented focused on individuals - often as patient, on the other hand, strategies informed by social research advocated a reflexive relationship, taking into account the lived experiences of those at most risk. Although epidemiology is good at looking at how diseases behave within populations, group (in the sense of connected individuals) behaviour is a blind spot. While the identification of risk by epidemiology is 'true' enough, this depiction debars its object-those 'at risk'- from doing anything about it, thereby suggesting that some other agency must. Social science, in critiquing the scientific presumption of an external and absolutely knowable referent has made us all, the social to a greater degree than the medical scientists, develop a conversation with those affected (the putative 'objects' of medical science) to reach desired outcomes (Rosengarten, 2001).

We agree with Rosenbrock et al. (2000): a socially informed public health has been more successful to date in combating the spread of HIV. Where the medical and epidemiologically informed public health emphasises early detection, mass screening, individual counseling and contact tracing, and treatment, the social public health, in acknowledging the dynamic patterning of practice and its cultural and social production, emphasises the involvement of communities and the agency of their individual members, the tailoring of prevention and health messages for collectives rather than for individuals, and harm reduction. Except in a very few countries, the medical and epidemiologically informed public health has been comparatively ineffective especially in stemming epidemics fuelled by sexual practice (Rosenbrock et al., 2000).

The technical efficacy of a social public health relates to the fact that the type of experts recognised as legitimate spokespersons included experts of social practice and members of affected communities. The knowledge that a social public health brought was that the affected communities and individuals were actively 
and productively engaged in the problem, that this was itself a resource, and that a response that did not take account of this was likely to fail. That is, those informing the social public health identified a protective agency among the affected, which they then endeavoured to enhance. This in turn led to strategies that trusted and supported affected groups and individuals to respond, and focused on information campaigns and accessible and sustainable safety measures - rather than relying on the state to protect the public through punitive measures and quarantine-style measures applied to individuals according to 'risk groups' and medical status (Stengers, 1997). With varying levels of success, the 'public' of the social public health included those affected, rather than excising them from the public sphere as 'bad objects'. A social public health, informed by social science, brought with it "[a] new prevention concept ... that aimed at influencing the social environment in a way that would strengthen people's motives for preventive behaviour and that would optimize the preconditions for communication with and within target groups and/or communities" (Rosenbrock et al., 2000, p. 1611).

\section{Outcomes of prevention messages}

The empirical findings of studies conducted during the period prior to introduction of successful treatments, support the comparative advantage of the 'social over the medical/epidemiological public health. During this period, a period in which the social public health gained ground, there is no doubt that there was an uptake of condoms and a sustaining of safe sexual practice - see Kippax, Connell, Dowsett, and Crawford (1993) in Australia; Hickson et al. (1996) in the UK; Moatti, Souteyrand, Prieur, Sandfort, and Aggleton (2000) and Moatti and Souteyrand (2000) in Europe more generally; Stall, Coates, and Hoff (1988), Schechter et al. (1988); Moran, Janes, Peterman, and Stone, 1990; Myers, McLeod, and Calzavara (1991) and Remis et al. (2000) in parts of North America. Furthermore, the strategies that were in the main most successful were the harm reduction strategies, the strategies based on a mutually acceptable description of safety from the interested positions of official science (both medical and social science) and from affected communities. These were the strategies embraced by the social public health.

Gay men largely ignored the call to abstinence. Martin (1987) and Evans et al. (1989) documented decreases in the early $1980 \mathrm{~s}$ in anal intercourse particularly that involving ejaculation, oral-genital sex with ejaculation, and rimming. By 1988, however, there was a return to what appeared to be earlier levels of sexual activity (Stall, Hays, Waldo, Ekstrand, \& McFarland, 2000 in the United States), but there was also a turn to the use of condoms and an expansion of the sexual repertoire in terms of the adoption of relatively safe sexual practices - at least between 1986 and 1996 in Australia (Kippax, 2001).

Furthermore, although early in the epidemic, gay men heeded the medical calls for monogamy, this strategy was not adhered to over time. There is some evidence from Martin (1987) of a decline in the median number of partners from five to three in the 12 months prior to interview and a move to one regular partner in the early years of the epidemic. By the time those findings were published, however, findings from a number of studies in the USA reviewed by Stall et al. (2000) indicate a move back to higher numbers of casual partners and these numbers remained reasonably stable over the next 10 years. Not only did the number of casual partners remain stable during the period between 1987 and 1997 and at higher levels than that reported by Martin (1987), but men in regular relationships engaged in casual sex outside their relationship.

In other words, between 1986/7 and 1996/7-in the USA and in Australia - among gay men, there was an uptake of certain prevention messages - condom use for anal intercourse and an expansion of the 'safe' sexual repertoire and the adoption of negotiated safety, and a turn away from others-abstinence and monogamy. Not only in these years did gay men choose some strategies and eschew others, there is evidence for the effectiveness of the strategies adopted by gay men (Anderson, 2000), including negotiated safety (Kinder, 1996; Kippax et al., 1997; Davidovich, de Wit, \& Stroebe, 2000; Crawford, Rodden, Kippax, \& Van de Ven, 2001). The medical advance of the HIV antibody test produced a new prevention strategy alongside others such as condom use and the avoidance of unprotected penetrative sex.

Although the evidence is not as clear-cut, there have been few if any heterosexual transmission-led epidemics in the developed world. Studies of the impact of sex education in schools indicate that there is no earlier initiation of sexual activity and that sexual activity is more likely to be safe among students receiving sex education compared with those who have not (Grunseit, Kippax, Aggleton, Baldo, \& Slutkin, 1997). Similarly, there is no evidence for a decline in drug use (the "war on drugs' proving particularly ineffective), and the presence of needle \& syringe programmes are generally associated with decline in HIV (Des Jarlais, Friedmann, Hagan, \& Friedman, 1996; Des Jarlais et al., 1998, 2000). ${ }^{2}$

\footnotetext{
${ }^{2}$ With the exception of Sweden, countries with needle and syringe programmes continue to have lower rates of HIV among populations of drug users than countries that do not. Methadone maintenance programmes have been shown to be effective in reducing risk behaviour and HIV seroconversion in a range of cities in USA, and in Berlin, Sydney, Amsterdam and Verona (Gibson, Flynn, \& McCarthy, 1999).
} 
Gay men, injecting drug users and, to some degree, heterosexuals moved to make their practices safe-by modifying and building on them, not by abstaining from or eliminating them. With reference to sexual practice, a range of strategies was developed over time and, as we show below, strategies continue to be produced by gay men. Some of these strategies are associated with an avoidance of condoms and related in complex ways to fidelity and love (Kippax, Crawford, Waldby, \& Benton, 1990). Although as noted above, monogamy bears some superficial similarity to negotiated safety, the uncritical assumption of monogamy by couples has shortcomings, particularly for women (Kippax, Crawford, \& Waldby, 1994). The realities of everyday life undermine the effectiveness of monogamy as a strategy: mutual monogamy while not uncommon is not universal, serial monogamy is the norm - especially among the young.

While medical knowledge about the modes of transmission was important, medical knowledge was transformed as gay men and injecting drug users took up this knowledge. With the help of educators and social researchers, they used it to fashion prevention strategies that, although not $100 \%$ risk-free, could be built into the everyday patterning of their lives and were sustainable. By the beginning of 1996, although the battle had not been won, it seemed that prevention efforts were succeeding. Succeeding because medical knowledge was being taken up and socially transformed by those most affected by the epidemic. This occurred with the help of social research and a new social public health that positioned members of affected communities as agents, who had taken up the challenge of HIV and engaged with various knowledges - from the medical and social sciences as well as from their own everyday experiencein order to preserve themselves, their partners, and communities.

\section{Post-Vancouver-post crisis (1996-2001)}

In 1996 at the 11th International AIDS Conference in Vancouver, Dowsett and McInnes (1996) presented new findings concerning gay communities in Australia, and coined the term 'post-AIDS', a term that has since been taken up in the United States of America (Rofes, 1998). Their term 'post-AIDS' referred to the sense that, in the developing world, the crisis had passed-prevention efforts were succeeding and people were learning to live with the epidemic. At the same conference, the success of new combination antiviral therapies (HAART) was announced and soon after post-exposure prophylaxis measures for occupational and non-occupational exposure to HIV were introduced. Somewhat serendipitously, the success of treatments became implicated in 'post-AIDS'.
HAART changed the face of AIDS. In the short-term antiviral treatments are proving effective. Viral load is reduced and the immune system boosted at least for the majority who takes treatments up. There is evidence from around the developed world of declining illness and fewer deaths. For example, pooled European data show an overall decline of $64 \%$ in the risk of dying within 10 years of developing HIV (Mocroft et al., 2000) and similar declines have been noted in Australia (Law, Li Yeuming, McDonald, Cooper, \& Kaldor, 2000). So, while there is still no cure and no certainty about the rate at which progression from HIV to AIDS to death will occur, HIV is now considered by many to be a chronic and controlled illness. Notwithstanding severe side effects for some and the problems of compliance, resistance and super-infection, antiviral therapy also means renewed energy, a return to work, and the possibility of a longer life of reasonable quality for most with HIV.

Not only have treatments lengthened life expectancy and improved quality of life, treatments have also been used very effectively to reduce mother-to-child transmission of HIV (Sperling et al., 1996; Mofenson et al., 1999). There is also evidence that transmission of HIV is less likely among those with low viral load: Quinn et al. (2000) reported that among the 415 serodiscordant heterosexual couples in their Ugandan study, the rate of transmission rose from $2.2 \%$ among individuals with viral RNA levels less than 3500 copies to $23.0 \%$ at levels greater than 50,000 copies. Viral load was the factor that most strongly predicted the risk of transmission.

Thus, where treatments are accessible, they have become directly implicated in prevention - the use of post-exposure prophylaxis, the prevention of mother-tochild transmission and, where treatment uptake is high in a population, the reduction in transmission as a result of reduced population viral load (Law, Prestage, Grulich, Van de Ven, \& Kippax, 2001). Indeed Warner (1999) has suggested that the lack of universal treatment access in the USA is a squandered opportunity and may have contributed to the ballooning incidence among African and Hispanic American communities in New York.

Notwithstanding the impact of treatment on reducing the likelihood of HIV-transmission, tensions between the medical and the social rapidly surfaced. In 1996 there was, and there continues to be, a concern that new treatments and access to post-exposure prophylaxis encourages risk taking among both seropositive and seronegative people - particularly in the context of the success of prevention (Horton, 1998). There is concern that there will be a return to the 'bad old days and ways'.

There is evidence to support these concerns in as much as the success of new treatments has fed increasing optimism in the developed world - particularly among those living with HIV and in communities most affected 
by HIV. Not only is contracting AIDS perceived as less serious now than prior to 1996 , treatments have led to a belief among some HIV-negative gay men that their personal risk of HIV-transmission is diminished. While the optimism is tempered by caution and scepticism, there are signs that in a number of countries-including Australia (Van de Ven, Prestage, French, Knox, \& Kippax, 1998) and the United States (Stall et al., 2000) - unprotected anal intercourse is on the increase. Already there is evidence of a small but significant relationship linking optimism to risk practice (Van de Ven, Kippax, Knox, Prestage, \& Crawford, 1999; Van de Ven, Prestage, Crawford, Grulich, \& Kippax, 2000; Katz et al., 2002). A decrease in HIV-testing among young gay men in Australia also points to a diminished concern, and optimism about the future course of the epidemic (Van de Ven, Prestage, Knox, \& Kippax, 2000).

In general, as Stall et al. (2000) observe, the evidence from studies of HIV incidence indicates that at best HIV incidence among homosexually active men has not decreased over the 1990s. There is an indication of a slight but worrying increase - at least in Ontario, Canada (Calzavara et al., 2000) and in San Francisco (Kellogg, McFarland, \& Katz, 1999; McFarland et al., 2000). No increases have been found in Australia (McDonald \& Musto, 2001) and few reported in Europe to date, although there are increasing rates of sexually transmissible infections among homosexually active men in many developed countries (Stall et al., 2000).

As well as the concern about optimism and its association with a return to unprotected sex, there is another concern: a concern that the success of new treatments has led to an increased focus on things medical - viral load, immune response, viral resistance and compliance. This turn to the medical, it is feared, has produced a renewed interest in individualised forms of health promotion and education - voluntary counselling and testing. It is also feared that this refocus on the medical may, in turn, fracture communities once united by the threat of HIV: separating positive from negative, and those with high viral load from those with undetectable or low viral loads.

Rosenbrock and his colleagues have raised such concerns about (re)medicalisation, and a return that they refer to as the 'old' (clinical/epidemiological) public health that parallels the concern of a return to the 'bad old days and ways'. This move may also entail a risk of abandoning exceptionalism and as noted by Horton (1998) and Rosenbrock et al. (1999), the normalisation of HIV and AIDS and the associated increasing neglect of behavioural prevention and a move of resources from 'care' to 'cure'. The neglect of prevention in the context of an increased attention to treatments has recently been questioned in reference to Africa (Creese, Floyd, Alban, \& Guinness, 2002).
The epidemiological/medical public health not infrequently takes the 'public' out of health, as illustrated by the promotion of voluntary counselling and testing as an HIV prevention strategy (Coates, 1998). If testing is driven by a renewed interest in secondary prevention (early detection, screening (voluntary or compulsory), case finding, compulsory partner notification, and treatment) then it does indeed take the 'public' out of health. However testing or, for that matter, measuring viral load do not have to be so positioned. If testing is driven by an interest in providing a range of safe sex options for all, both HIV-negative and HIV-positive people, then the medical can be successfully integrated and incorporated into primary HIV-prevention. As we have shown, the HIV antibody test can be and is used in negotiating safe sex without condoms; the gay community worked to establish a culture of honesty within relationships (Kippax \& Kinder, 2002). Similarly a 'social public health response' is needed to address the technologies associated with viral load measures, where 'public' means "accessible, available to memory, and sustained through collective activity" (Berlant \& Warner, 1998, p. 547 [our emphasis]).

As Race (2001) has argued, it is vitally important not to see the changes post-1996 as a return to the 'old ways' but rather a taking up of a new post-crisis position that has its own dynamic. While it is true that prior to 1996, the antibody test produced a new identity - the PLWHA (people living with HIV and AIDS), it also produced a response to such fracturing of gay community. The identity, PLWHA, was a cultural and politicised identity with its own set of interests and concerns, which did often differ from those of prevention. The question now, post-1996, is how are these new medical developments being responded to both by those living with HIV and AIDS, and by those who are at risk of infection. Is the social science narrative in danger of being undermined? What collective and cultural responses are required to mediate and transform the medical?

\section{Transformations of the medical}

The finding, in Australia, that there are substantial increases in risky sexual practice among gay men, in particular, increases in unprotected anal intercourse, yet stable rates in HIV seroconversions among gay men, raises an important question. Stall et al. (2000) and Law et al. (2001) provide a possible explanation in terms of an uptake of antiretroviral therapy among gay men and the resulting reduced population viral load and lowered risk of HIV transmission. While we believe that may be part of the answer, we offer an additional explanation, one which Stall et al. (2000) gesture towards and for which we have some evidence.

In a recent in-depth qualitative study of gay men in Sydney and Brisbane (Rosengarten, Race, \& Kippax, 
2000) investigating the impact of new therapies on gay men's sexual practice, a number of risk reduction strategies other than condom use and negotiated safety were identified. Gay men talked of withdrawal before ejaculation as a way of reducing risk and, depending upon their HIV antibody status, on being either the insertive or receptive partner in unprotected anal intercourse. In particular, HIV-positive men also spoke of low or 'undetectable' viral load and lowered risk of infection. Differences in understanding and knowledge of recent medical advances run the risk of mismatched risk-reduction strategies. For example, the widespread expectation that HIV-positive men will disclose their status when having sex is because people are still not well enough informed of how men identified by medicine as positive are (privately) making sense of their sociomedical situation.

Quantitative data tell a similar story (Van de Ven et al., 2002). Pooled survey data on men's sexual practice in Sydney 1996-2000 investigating the degree to which men engaged in unprotected anal intercourse in the six months prior to interview (to get into this category men had only to engage in UAI once) with either their casual partner or their serodiscordant regular partner (the two practices considered to be markers of risk), confirmed the findings of Rosengarten et al. (2000). When engaging in unprotected anal intercourse, HIV-negative men in casual encounters are more likely than not to adopt the insertive mode/position while HIV-positive men are more likely to be receptive. This finding is stronger in serodiscordant relationships in which sexual partners are more likely to share knowledge and understandings of viral load and other clinical markers. When the behaviour of same men was examined when they used condoms, the pattern completely disappeared and reciprocity returned. We called this strategy 'strategic positioning' and further analyses of the same data indicate an increase in the number of men adopting this strategy over time (Rawstorne, 2002, pers. comm.).

Whatever one thinks of these condom-avoidant HIV prevention strategies - withdrawal, being insertive if HIV-negative and receptive if HIV-positive (strategic positioning), reliance on undetectable viral load, and negotiated safety - they do not speak to relapse or a return to the 'bad old days and ways'. While the spread of these attempts to reduce HIV-transmission risk remains to be empirically described, they speak to the adoption of a range of considered strategies - strategies taken up to reduce harm - to themselves and their sexual partners. These strategies, which are reliant on knowledge of clinical markers (both HIV status and viral load), appear to have been added to others that have been there from the beginning of the epidemic - such as condom use. They are a response to the medical: an appropriation and enculturation of medical knowledge. What also remains to be tested is whether strategic positioning and other harm reduction strategies will be sufficient to prevent an increase in HIV incidence.

In this regard whatever the uncertainties (and there are many), HIV-prevention and health promotion officials need to monitor these strategies carefully and attend to them - particularly in the context of increasing rates of sexually transmissible infections, and some indication of increases in HIV incidence. Whatever these increases indicate, if successful HIV harm reduction HIV-prevention and campaigns are to be developed, these strategies must be understood. To ignore them is to promote HIV-prevention messages that miss their mark. There is little evidence of an abandonment of a safe sex culture. Rather there is evidence that the medical knowledge continues to be incorporated in gay men's understandings of risk (at least in Australia) - and they are modifying their practice in response. This is not a picture of gay men throwing caution to the wind. This is a picture of gay men using medical and epidemiological knowledge to think about how much risk they are prepared to take and under what conditions. This process has historically given rise to practices and norms, like condom use, and will continue to do so. The question is whether these new risk reduction strategies should be promoted and if so how? Will the strategies described above mean the end to a safe sex culture? These are the vexing questions that currently face educators and prevention experts.

\section{Conclusions - a social public health}

What was learnt in the early 'prevention only' days of the epidemic (up to 1996) was that successful strategies depend upon the following: partnerships between government, non-government organisations and affected communities, reflexive relationships between researchers, educators and communities, and the necessity of acknowledging the changing and disparate patterning of practice and its social and cultural production - what we have termed a social public health (Rosenbrock et al., 1999, 2000). Rosenbrock et al. (2000, p. 1610) speak of the importance of an "exceptionalist alliance" which, depending on the particular country, included gay community, liberal and left-wing parties, and/or large sections of the health care and psychosocial professions.

What this social public health and the alliance of the social and medical sciences enabled was what the data above show: a successful response that was dependent on the affected communities - gay men (and drug users) - being positioned and positioning themselves as agents - responsible agents - in charge of their own lives and the well-being of their communities. Despite powerful individualising ideologies, it continues to be 
important to endeavour to frame HIV as a collective concern.

The big risk in the new environment, post-HAART, is that science will again pretend that it can make total claims. To the extent that this occurs, the affected will be positioned as mere objects rather than agents and the medical sciences will have no way of knowing, working with, or registering the significance of the meanings of the clusters of practices that are harmful, whether they are modifiable and how such modification may be achieved. However, while it is true that medical technologies have the potential to undermine safe sex, it is also true that medicine can be used in an agentive way and, as in the case of negotiated safety and more recently the viral load test, health promotion needs to make special efforts. So as well as the conservation of condom culture, an additional task for education arises: to provoke the new norms and make them publicagain meaning 'accessible, available to memory, and sustained through collective activity'.

In post-structuralist terms, the objects of science are always an effect of the means by which they are made known. Like maps, the risk sciences depict "models of worlds crafted through and for specific practices of intervening" (Haraway, 1997, p. 135). The case of HIV suggests that there is something important about how the risk sciences' determination of objects (e.g. whether risk is located in terms of promiscuity or unprotected anal intercourse) must be entertained in conversation by the human subject to whom they pertain and for whom they are meaningful - and who ultimately must invent ways of modifying their embodied practice if they are to survive. A lesson to be drawn from HIV is that this is best done in the recognition that these meanings are socially and culturally produced - even if also multivaried and subjective - and that human beings have the capacity and will to problematise and act on their embodied habits (albeit within limits and according to the specific and situated investments in the body).

While not ignoring the concerns of Horton (1998), Rosenbrock et al. (1999) and Rosenbrock et al. (2000), we have argued here that the new medical technologies do not necessarily mean a return to the 'bad old days' of the old public health — or to an abandonment of safe sex (post-AIDS). We suggest instead that opposing treatments to prevention might not be the way to think about the issue. Indeed, as the analysis above has shown, treatments in a very real sense are part of the prevention story. Among gay men in Australia at least there has not been a wholesale embracing of medical technologies at the expense of HIV-prevention strategies. Gay men have already begun to take the medical in(to) their practice. Such an integration or interdiscursivity presents health promotion and behavioural intervention with two challenges. The first challenge is how to continue to develop well-informed and increasingly complex beha- vioural prevention messages that incorporate new medical knowledge about clinical markers, such as test status and viral load. The second is to ensure that the partnership, the alliance, between medicine and social science is a genuine one. If gay men and members of other communities affected by HIV continue to take up the medical in an agentic creative way and are not positioned merely as passive recipients of medicine, then there is less need to fear 'medicalisation'. If HIVprevention incorporates medicine and not vice versa, then it is unlikely that primary HIV-prevention will be sidelined.

There is a critical need for the reassertion of the primacy of prevention and there is a need for a new prevention activism in this age of new treatments and promise of vaccines, we need an approach to prevention that once again integrates the medical and the social narratives. Medical advances unsettle sexual norms in ways that could lead to mistaken assumptions and expectations - for both HIV-positive and HIV-negative people. The key challenge for health promotion is to identify and mark the collective effects and dimensions of these new locations of risk. The knowledge that is found wanting is not medical, but rather the sociocultural knowledge of the field.

Above all, we need to "...attend critically to the current arrangement of risk and responsibility, and to intervene in it.... At this point in the epidemic, this requires us to examine closely the mechanisms of knowledge about risk, and invent ways of better distributing their pressures." (Race, 2001, p. 186).

\section{Acknowledgements}

The National Centre in HIV Social Research is funded by the Commonwealth Department of Health and Aged Care.

We would also like to acknowledge the help of our colleagues at the National Centre in HIV Social Research in Australia.

\section{References}

Adam, P. (1999) Unprotected sex with stable and casual partners among French gay men in a steady relationship, according to HIV status, paper presented at the 10th conference on social aspects of AIDS, London, UK

Anderson, R. (2000). Successes in HIV control, fact or fiction plenary? Paper presented at XIII international AIDS conference. Durban, South Africa.

Bajos, N., \& Marquet, J. (2000). Research on HIV sexual risk: Social relations-based approach in a cross-cultural perspective. Social Science and Medicine, 50, 1533-1546. 
Ballard, J. (1989). The politics of AIDS. In H. Gardner (Ed.), The politics of health: The Australian experience (pp. 349-375). Melbourne: Churchill Livingstone.

Ballard, J. (1998). The constitution of AIDS in Australia: Taking 'government at a distance' seriously. In B. Hindess, \& M. Dean (Eds.), Governing Australia (pp. 125-138). Melbourne: Cambridge University Press.

Bennett, W. J. (1987). AIDS: Education and public policy. International Review of Natural Family Planning, 11(2), 146-157.

Berlant, L., \& Warner, M. (1998). Sex in public. Critical Inquiry, 24(2), 547-566.

Brown, T. (2000). AIDS, risk and social governance. Social Science and Medicine, 50, 1273-1284.

Callen, M. (1983). How to have sex in an epidemic. New York: News from the Front Publications.

Calzavara, L., Burchell, A., Major, C., Remis, R., Corey, P., Myers, T., Wallace, E., Millson, M., \& the Polaris Study Team (2000). Increasing HIV incidence among MSM repeat testers in Ontario, Canada, 1992-1998. Paper presented at XIII international conference on AIDS. Durban, South Africa.

Coates, T. J. (1998). HIVIAIDS prevention in the context of new therapies. Geneva: UNAIDS Best Practice Collection.

Coates, T. J., Aggleton, P., Bayer, R., Gutzwiller, F., Des Jarlais, D., Kiharo, M., Kippax, S., Schechter, M., \& van den Hoek, J. A. R. (1996). HIV prevention in developed countries. The Lancet, 348, 1143-1148.

Collomb, K., \& Howard, M. (1988). Georgia schools help teens postpone sexual involvement. Journal of the Medical Association of Georgia, 77(4), 230-232.

Conant, M., Hardy, D., Sernatinger, J., Spicer, D., \& Levy, J. A. (1986). Condoms prevent transmission of AIDSassociated retrovirus [letter]. Journal of the American Medical Association, 255(13), 1706.

Crawford, J., Rodden, P., Kippax, S., \& Van de Ven, P. (2001). Negotiated safety and other agreements between men in relationships: Risk practice redefined. International Journal of STD and AIDS, 12, 164-170.

Creese, A., Floyd, K., Alban, A., \& Guinness, L. (2002). Cost effectiveness of HIV/AIDS interventions in Africa: A systematic review of the evidence. The Lancet, 359, 1635-1642.

Davidovich, U., de Wit, J. B. F., \& Stroebe, W. (2000). Assessing sexual risk behaviour of young gay men in primary relationships: The incorporation of negotiated safety and negotiated safety compliance. AIDS, 14, 701-706.

Davies, P. M. (1993). Safer sex maintenance among gay men: Are we moving on the right direction? [letter]. AIDS, 7, 2279-17062280.

De Gruttola, V., Mayer, K., \& Bennett, W. (1986). AIDS: Has the problem been adequately addressed. Reviews of Infectious Diseases, 8(2), 295-305.

Des Jarlais, D. C., Perlis, T., Friedman, S. R., Deren, S., Sotheran, J. L., Tortu, S., Beardsley, M., Paone, D., Torian, L. V., Beatrice, S. T., DeBernado, E., Monterroso, E., \& Marmor, M. (1998). Declining seroprevalence in a very large HIV epidemic: Injecting drug users in New York City, 1991-1996. American Journal of Public Health, 88, 1801-1806.
Des Jarlais, D. C., Friedmann, P., Hagan, H., \& Friedman, S. R. (1996). The protective effect of AIDS-related behavioural change among injection drug users. A crossnational study. American Journal of Public Health, 86, 1780-1785.

Des Jarlais, D. C., Marmor, M., Perlis, T., Friedmann, P., Titus, S., Aviles, E., Torian, L. V., Glebatis, D., Murrill, C., Monterroso, E., \& Friedman, S. R. (2000). HIV incidence among injecting drug users in New York City, 1992 to 1997: Evidence of a declining epidemic. American Journal of Public Health, 90, 35-359.

Dowsett, G.W., \& McInnes, D. (1996). 'Post-AIDS': Assessing the long-term social impact of HIV/AIDS in gay communities. Paper presented at the XI international conference on AIDS, Vancouver.

Elford, J., Bolding, G., Maguire, M., \& Sherr, L. (1999). Sexual risk behaviour among gay men in a relationship. AIDS, 13, 1407-1411.

Evans, B., McLean, K., Dawson, S., Teece, S., Bond, R., MacRae, L., \& Thorp, R. (1989). Trends in sexual behaviour and risk factors for HIV infection among homosexual men, 1984-7. British Medical Journal, 289, 215-218

Friedman, S. R., Curtis, R., Neaigus, A., Jose, B., \& Des Jarlais, D. C. (1999). Social networks, drug injectors' lives, and HIVIAIDS. New York: Kluwer/Plenum.

Friedman, S. R., Des Jarlais, D. C., Sotheran, J. L., Garber, J., Cohen, H., \& Smith, D. (1987). AIDS and self-organization among intravenous drug users. International Journal of the Addictions, 22(3), 201-219.

Gibson, D. R., Flynn, N. M., \& McCarthy, J. J. (1999). Effectiveness of methadone treatment in reducing HIV risk behaviour and HIV seroconversion among injecting drug users. AIDS, 13, 1807-1818.

Gochros, H. L. (1988). Risks of abstinence: Sexual decision making in the aids era. Social Work, 33, 254-256.

Goedert, J. J. (1987). What is safe sex? Suggested standards linked to testing for human immunodeficiency virus. New England Journal of Medicine, 316, 1339-1342.

van Griensven, G. J., de Vroome, E. M., Goudsmit, J., \& Coutinho, R. A. (1989). Changes in sexual behaviour and the fall in incidence of HIV infection among homosexual men. British Medical Journal, 298, 218-221.

van Griensven, G. J., de Vroome, E. M., Tielman, R. A., \& Coutinho, R. A. (1988). Failure rate of condoms during anogenital intercourse in homosexual men. Genitourinary Medicine, 64(5), 344-346.

Grunseit, A., Kippax, S., Aggleton, P., Baldo, M., \& Slutkin, G. (1997). Sexuality education and young people's sexual behaviour: A review of studies. Journal of Adolescent Research, 2(4), 421-453.

Haraway, D. (1991). Simians, cyborgs, and women: The reinvention of nature. London: Free Association Books.

Haraway, D. (1997). Modest witness@second millennium. FemaleMan meets Onco mouse: Feminism and technoscience. New York: Routledge.

Hickson, R., Reid, D., Davies, P., Weatherburn, P., Beardsell, S., \& Keogh, P. (1996). No aggregate change in homosexual HIV risk behaviour among gay men attending the Gay Pride festivals, United Kingdom, 1993-1995. AIDS, 10, 771-774. 
Horton, M. (1998) AIDS virtually normal now. Paper presented at the XII international AIDS conference, Geneva.

Ingham, R., Woodcock, A., \& Stenner, K. (1992). The limitations of rational decision-making models as applied to young people's sexual behaviour. In P. Aggleton, P. Davies, \& G. Hart (Eds.), AIDS: Rights, risk and reason (pp. 163-173). London: The Falmer Press.

Katz, M. H., Schwarcz, S. K., Kellogg, T., Klausner, J., Dilley, J., Gibson, S., \& McFarland, W. (2002). Impact of highly active antiviral treatment on HIV seroincidence among men who have sex with men: San francisco. American Journal of Public Health, 92(3), 388-394.

Kellogg, T., McFarland, W., \& Katz, M. (1999). Recent increases in HIV seroconversions among repeat anonymous testers in San Francisco. [letter]. AIDS, 13, 2303-2304.

Kinder, P. (1996). A new prevention education strategy for gay men: Responding to the impact of AIDS on gay men's lives. Paper presented at the XI international AIDS conference, Vancouver.

Kippax, S. (2001). Sexual behaviour in the era of AIDS: Changes among Australians' sexual practice 1986-1999. Journal of Asian Sexology, 2, 68-70.

Kippax, S., Connell, R. W., Dowsett, G. W., \& Crawford, J. (1993). Sustaining safe sex: Gay communities respond to aids. London: Falmer Press.

Kippax, S., \& Crawford, J. (1993). Flaws in the theory of reasoned action. In D. J. Terry, C. Gallois, \& M. M. McCamish (Eds.), The theory of reasoned action: Its applications to AIDS-preventive behaviour (pp. 253-269). Oxford: Pergamon.

Kippax, S., Crawford, J., Davis, M., Rodden, P., \& Dowsett, G. W. (1993). Sustaining safe sex: A longitudinal study of a sample of homosexual men. AIDS, 7, 257-263.

Kippax, S., Crawford, J., \& Waldby, C. (1994). Heterosexuality, masculinity and HIV: Barriers to safe heterosexual practice. AIDS, 8(suppl.1), S315-S323.

Kippax, S., Crawford, J., Waldby, C., \& Benton, P. (1990). Women negotiating heterosex: Implications for AIDS prevention. Women's Studies International Forum, 13(6), 533-542.

Kippax, S., \& Kinder, P. (2002). Reflexive practice: The relationship between social science and health promotion in HIV prevention. Sex Education, 2(2), 93-106.

Kippax, S., Noble, J., Prestage, G., Crawford, J. M., Campbell, D., Baxter, D., \& Cooper, D. (1997). Sexual negotiation in the 'AIDS era': Negotiated safety revisited. AIDS, 11(2), 191-197.

Law, M.G., Li Yeuming, McDonald, A.M., Cooper, D., \& Kaldor, J. (2000). Estimating the population impact in Australia of improved antiviral treatment for HIV infection. AIDS, 14, 197-201.

Law, M. G, Prestage, G., Grulich, A., Van de Ven, P., \& Kippax, S. (2001). Modeling the effect of combination antiretroviral treatments on HIV incidence. AIDS, 15, 1287-1294.

Martin, J. L. (1987). The impact of AIDS on gay male sexual behavior patterns in New York City. American Journal of Public Health, 77(5), 578-581.

McDonald, A., \& Musto, J. (Eds.), (2001). Annual surveillance report: HIVIAIDS, viral hepatitis and sexually transmissible infections in Australia. Sydney: National Centre in HIV
Epidemiology and Clinical Research, University of New South Wales.

McFarland, W., Schwarcz, S., Kellogg, T.A., Hsu, L., Kim, A., \& Katz, M.H. (2000). Paper implications of highly active antiretroviral treatment for HIV prevention: The case of men who have sex with men (MSM) in San Francisco, Paper presented at XIII international conference on AIDS, Durban.

Moatti, J-P., \& Souteyrand, Y. (2000). HIV/AIDS social and behavioural research: Past advances and thoughts about the future. Editorial in symposium on sociobehavioural sciences on AIDS: New challenges. Social Science and Medicine, 50, 1519-1532.

Moatti, J-P., Souteyrand, Y., Prieur, A., Sandfort, T., \& Aggleton, P. (2000). AIDS in Europe: New challenges for the social sciences. London and New York: Routledge.

Mocroft, A., Katlama, C., Johnson, A.M., Pradier, C., Antunes, F., Mulcahy, F., Chiesi, A., Phillips, A.N., Kirk, O., \& Lundgren, J.D. for the EuroSIDA Study Group (2000). AIDS across Europe, 1994-98: The EuroSIDA study. The Lancet, 356, 291-296.

Mofenson, L. M., Lambert, J. S., Stiehm, E. R., Bethel, J., Meyer, W. A., Whitehouse, J., Moye, J., Reichelderfer, P., Harris, D. R., Fowler, M. G., Matheison, B. J., \& Nemo, G. J. (1999). Risk factors for perinatal transmission of human immunodeficiency virus type 1 in women treated with zidovudine. New England Journal of Medicine, 341(6), 319-385.

Moran, J. S., Janes, H. R., Peterman, T. A., \& Stone, K. M. (1990). Increase in condom sales following AIDS education and publicity, United States. American Journal of Public Health, 80(5), 607-608.

Myers, T., McLeod, D.W., \& Calzavara, L. (1991). Responses of gay and bisexual men to HIV/AIDS in Toronto, Canada: community-based initiatives, AIDS education, and sexual behaviour. Unpublished report, Toronto: HIV Social, Behavioural and Epidemiological Studies Unit, Faculty of Medicine, University of Toronto.

Paicheler, G. (2000). Understanding risk management. In J-P. Moatti, Y. Souteyrand, A. Prieur, T. Sandfort, \& P. Aggleton (Eds.), AIDS in Europe: New challenges for the social sciences. London and New York: Routledge.

Patton, C. (1990). Inventing AIDS. New York: Routledge.

Quinn, T. C., Wawer, M. J., Sewankambo, N., Serwadda, D., Li, C. J., Wabwire-Mangen, F., Meehan, M. O., Lutalo, T., \& Gray, R. H. (2000). Viral load and heterosexual transmission of human immunodeficiency virus type 1 . New England Journal of Medicine, 342(13), 921-929.

Race, K. (2001). The undetectable crisis: Changing technologies of risk. Sexualities, 4, 167-189.

Rawstorne, P. (2002). Personal communication, February, National Centre in HIV Social Research, University of New South Wales, Sydney, NSW 2052, Australia.

Remis, R. S., Major, C., Calzavara, L., Myers, T., Burchell, A., \& Whittingham, E. P. (2000). The HIV epidemic among men who have sex with other men: the situation in Ontario in the year 2000. Ontario: Department of Public Health Services, University of Toronto.

Rofes, E. (1998). Dry bones breathe: Gay men creating postAIDS identities and cultures. New York: Harrington Park Press. 
Rosengarten, M. (2001). Irony and paradox in HIV containment. Paper presented at social studies of science society conference. Boston, November.

Rosengarten, M., Race, K., \& Kippax, S. (2000). Touch wood, everything will be OK: Gay men's understandings of clinical markers in sexual practice (monograph 7/2000). Sydney: National Centre in HIV Social Research, The University of New South Wales.

Rosenbrock, R., Dubois-Arber, F., Moers, M., Pinell, P., Schaeffer, D., \& Setbon, M. (2000). The normalization of AIDS in Western European countries. Social Science and Medicine, 50, 1607-1629.

Rosenbrock, R., Schaeffer, D., Dubois-Arber, F., Moers, M., Pinell, P., Setbon, M.withBromme, N., \& Groger, A. (1999). The AIDS policy cycle in Western Europe: From exceptionalism to normalization. Berlin: Research Unit, Public Health Policy.

Ross, M. (1987). Responses of homosexual men to AIDS [letter]. Medical Journal of Australia, 146, 180.

Schechter, M. T., Craib, K. M., Willoughby, B., Douglas, B., McLeod, W. A., Maynard, M., Constance, P., \& O'Shaughnessy, M. (1988). Patterns of sexual behavior and condom use in a cohort of homosexual men. American Journal of Public Health, 78, 1535-1538.

Sperling, R. S., Shapiro, D. E., Coombs, R. W., Todd, J. A., Herman, S. A., McSherry, G. D., Osullivan, M. J., VanDyke, R. B., Jiminez, E., Rouzioux, C., Flynn, P. M., Sullivan, J. L., Spector, S. A., Diaz, C., Rooney, J., Balsley, J., Gelber, R., \& Connor, E. M. (1996). Maternal viral load, zidovudine treatment, and the risk of transmission of human immunodeficiency virus type 1 from mother to infant. New England Journal of Medicine, 335(12), $1621-1629$.

Stall, R. D., Coates, T. J., \& Hoff, C. (1988). Behavioral risk reduction for HIV infection among gay and bisexual men. A review of results from the United States. American Psychologist, 43, 878-885.

Stall, R. D., Hays, R. B., Waldo, C. R., Ekstrand, M., \& McFarland, W. (2000). The Gay '90s: A review of research in the 1990s on sexual behavior and HIV risk among men who have sex with men. AIDS, 14(suppl. 3), S101-S114.

Stengers, I. (1997). Power and invention: Situating science. Minneapolis, London: University of Minnesota Press.

Surgeon General's Report on Acquired Immune Deficiency Syndrome (1986). US National Library of Medicine.
Van de Ven, Paul, Kippax, S., Crawford, J., Rawstorne, P., Prestage, G., Grulich, A., \& Murphy, D. (2002). In a minority of gay men, sexual risk practice indicates strategic positioning for perceived risk reduction rather than unbridled sex. AIDS Care, 14, 471-480.

Van de Ven, P., Kippax, S., Knox, S., Prestage, G., \& Crawford, J. (1999). HIV treatments optimism and sexual behaviour among gay men in Sydney and Melbourne. AIDS, 13, 2289-2294.

Van de Ven, P., Prestage, G., Crawford, J., Grulich, A., \& Kippax, S. (2000). Sexual risk behaviour increases and is associated with HIV optimism among HIV-negative and HIV-positive men in Sydney over a four-year period to February 2000 [research letter]. AIDS, 14, 2951-2953.

Van de Ven, P., Prestage, G., French, J., Knox, S., \& Kippax, S. (1998). Increase in unprotected anal intercourse with casual partners among Sydney gay men in 1996-98. Australian and New Zealand Journal of Public Health, 22(7), 814-818.

Van de Ven, P., Prestage, G., Knox, S., \& Kippax, S. (2000). Gay men in Australia who do not have HIV test results. International Journal of STD and AIDS, 11, 456-460.

Waldby, C., Kippax, S., \& Crawford, J. (1993). Cordon Sanitaire: 'clean' and 'unclean' women in the AIDS discourse of young men. In P. Aggleton, P. Davies, \& G. Hart (Eds.), AIDS: Facing the second decade (pp. 29-39). London: Falmer Press.

Waldby, C., Kippax, S., \& Crawford, J. (1995). Epidemiological knowledge and discriminatory practice: Aids and the social relations of biomedicine. Australian and New Zealand Journal of Sociology, 31(1), 1-14.

Warner, M. (1999). The trouble with normal: Sex, politics and the ethics of queer life. Cambridge, Massachussets: Harvard University Press.

Washington Post (2001). Administration promoting abstinence; family planning efforts are being scaled back, www.aegis.org/news/ads/2001/ad010731.

Watney, S. (1990). Safer sex as community practice. In P. Aggleton, P. Davies, \& G. Hart (Eds.), AIDS: Individual, cultural and policy dimensions (pp. 19-33). London: Falmer Press.

de Zwart, O., Sandfort, T., \& van Kerkhof, M. (1998). No anal sex please: We're Dutch: A dilemma in HIV prevention directed at Gay men. In T. Sandfort (Ed.), The Dutch Response to HIV: Pragmatism and consensus (pp. 135-152). London: UCL Press. 